\title{
A RELAÇÃO ENTRE ESTADO E RELIGIÃO EM HEGEL
}

\author{
Paulo Roberto Konzen ${ }^{1}$
}

\begin{abstract}
Resumo: Para Hegel, o Estado e a religião concorrem juntos para formar o espírito do povo (Volksgeist). Por isso, a doutrina deles não pode ser qualquer uma. Bem pelo contrário, em Hegel, a religião e o Estado têm por conteúdo a verdade. Ambos a buscam, apenas a forma de apreendê-la é diferente. Hegel sabe que, para alguns pensadores, as doutrinas da religião e do Estado completam-se; para outros, elas divergem ou, mesmo, seriam opostos. Hegel, porém, crê e prega que as duas doutrinas coincidem ou, pelo menos, deveriam coincidir. Ou seja, na medida em que eles buscam um mesmo conteúdo, Hegel espera que a religião e o Estado reconheçam e apresentem a verdade, que dissipa todo erro. Contudo, também reconhece que eles podem vir a estar em oposição um ao outro, na medida em que a externação das suas doutrinas pode ser diversa e, inclusive, vir a ser oposta. Diante disso, procurando resolver um possível conflito, Hegel acaba apregoando que, quanto à externação, no âmbito do espírito objetivo, a religião pode e mesmo deve vir a passar para o domínio do Estado. Assim sendo, eis porque o presente artigo é uma tentativa de apresentação e análise da relação entre Estado e religião em Hegel, procurando destacar as principais razões pelas quais a externação da doutrina duma religião, no âmbito do espírito objetivo, pode vir a ter que ceder em favor da autoridade do Estado, apontando, para isso, elementos sobre o determinante conceito hegeliano de verdade ou de saber absoluto, objeto religioso e estatal. Para tal, basear-me-ei em textos clássicos e interpretativos hegelianos sobre a relação entre Estado e religião.
\end{abstract}

Palavras-chaves: Filosofia, Religião, Estado, Verdade, Crença, Política, Hegel.

Resumen: Para Hegel, el Estado y la religión concurren juntos para formar el espíritu del pueblo (Volksgeist). Por ese motivo, la doctrina de ellos no puede ser cualquiera una. Por el contrario, en Hegel, la religión y el Estado tienen como contenido la verdad. Ambos la buscan, sólo la forma de aprehenderla es diferente. Hegel sabe que, para algunos pensadores, las doctrinas de la religión y del Estado se completan; para otros, ellas divergen $\mathrm{o}$, incluso, se oponen. Hegel, sin embargo, cree y predica que las dos doctrinas coinciden $\mathrm{o}$, al menos, deberían coincidirse. Es decir, en la medida en que buscan un mismo contenido, Hegel espera que la religión y el Estado reconozcan y presenten la verdad, que disipa todo error. Sin embargo, también reconoce que ellos pueden estar en oposición entre sí, en la medida en que la externalización de sus doctrinas puede ser diversa e, incluso, ser opuesta. Teniendo en cuenta esto, buscando resolver un posible conflicto, Hegel acaba pregonando que, sobre la externalización, en ámbito del espíritu objetivo, la religión puede y, incluso, debe pasar al dominio del Estado. Así siendo, el objetivo del presente artículo es una tentativa de presentar y analizar la relación entre el Estado y la religión en Hegel, buscando destacar las principales razones por las que la exteriorización de la doctrina de una religión, en ámbito del espíritu objetivo, podría tener que ceder en favor de la autoridad del Estado,

\footnotetext{
${ }^{1}$ Professor Adjunto do Curso de Filosofia da UNIR. Doutor em Filosofia pela UFRGS. Autor de " $O$ Conceito de Liberdade de Imprensa ou de Liberdade da Comunicação Pública na Filosofia do Direito de G. W. F. Hegel" (2013), pela Editora Fi (http://www.editorafi.org/). E-mail: prkonzen@unir.br
} 
señalando, para esto, elementos sobre el determinante concepto hegeliano de verdad o de saber absoluto, objeto religioso y estatal. Para eso, me basaré en textos clásicos e interpretativos hegelianos sobre la relación entre el Estado y la religión.

Palabras-clave: Filosofía, Religión, Estado, Verdad, Creencia, Política, Hegel.

\section{Introdução: A filosofia de Hegel e a religiosidade}

Sobre a religiosidade, Hegel ressaltou que apenas o ser humano é religioso e o é por ser dotado da capacidade de pensar. "Só o homem é capaz de religião" (HEGEL, $1995^{1}$, p. 40). Nenhum outro ser, até hoje conhecido, é religioso, e isso só porque o ser humano tem como essência o pensar. Ou seja, segundo Hegel, "o pensar não tem estado inativo no que respeita à religião" (Ibidem). Antes, para Hegel, pelo pensamento, o espírito humano veio perceber o divino em si; no entanto, o princípio religioso, que habita nosso coração, precisa dar-se conta de si e saber que é livre (cf. HEGEL, 1999, p. 283 e 337). Em Hegel, o elemento vital é sempre o princípio da liberdade.

O pensamento, por conseguinte, mesmo que, inicialmente, sob forma pouca refletida, tem papel determinante na formulação dos problemas e na busca das respectivas soluções. Hegel, dessa forma, acaba sublinhando a universalidade do fato religioso; ele declara que a "religião é a espécie e modalidade da consciência, segundo a qual a verdade é para todos os homens" (HEGEL, 1995¹, p. 25), qualquer que seja seu grau de cultura. A razão dessa universalidade, como vimos, é porque só o ser humano é dotado da faculdade de pensar; os animais, como não têm essa faculdade, ignoram a religião, com também a moralidade e a justiça. Por faculdade de pensar, Hegel entende aquela atividade superior graças à qual o homem pode vir a apreender o eterno, o absoluto, objeto que seríamos incapazes de apreender pela razão especulativa, segundo a filosofia de Kant. Ora, Hegel considera que a religião tem um conteúdo muito complexo; ela comporta um lado afetivo, sendo como que uma disposição, um sentimento inferior que cabe ser moldado. Mas, é preciso que não se faça consistir nisso toda a essência da religião. Antes, as religiões, mesmo as mais primitivas, têm um credo, um ensinamento, uma dogmática; assim, suprimi-los ou minimizá-los, como teria tendência a fazer os pietistas, não é a atitude mais elevada. Hegel até verificou, com pesar, em sua época, que a religião foi contraindo, cada vez mais, o que havia de mais amplo em seu conteúdo, concentrando-se, por vezes, na piedade ou numa espécie de

\begin{tabular}{|l|l|l|l|l|}
\hline Qevista Dialectus & Ano 2 & n. 4 & Janeiro-Junho 2014 & p. 39-62 \\
\hline
\end{tabular}


mero sentimento. Para Hegel, a religiosidade é um campo digno para o trabalho da filosofia, segundo o qual uma e outra poderão conciliar-se. As religiões constituem quase sempre um conjunto muito complexo e não raro fortemente estruturado; é preciso levar tudo em consideração nesse conjunto e, particularmente, não negligenciar o que pode ser chamado de parte cognitiva da religião. Para Hegel, a ideia religiosa não pode ficar mergulhada nos limbos do sentimento ou da mera representação; ela deve manifestar-se e, manifestando-se, tomar uma forma determinada, constituir um ensinamento definido sobre as origens das coisas, da natureza do mundo e do homem, etc. Segundo Hegel, as religiões são, portanto, um esforço feito pela humanidade para penetrar o mistério de seu destino. Assim, mesmo suas limitações - se o são - não devem impedir-nos de ver nas religiões, até nas mais primitivas, ensaios de metafísica, adaptados, se podemos assim dizer, às capacidades intelectuais existentes, ao espírito do povo e ao espírito do tempo, como observa Hegel com frequência. Enfim, a religião foi uma preocupação originária, genuína e permanente na filosofia de Hegel.

\section{A necessidade da tarefa de apreender o saber absoluto}

Hegel prega que todo ser humano, na sua respectiva época, deve ter necessariamente em vista a tarefa de apreender o saber absoluto, ou seja, elaborar a filosofia que se sabe determinação última do automovimento da Ideia, que tem sua dita realização ao apreendê-la de modo adequado. Mas, para a filosofia poder apreender o saber absoluto, a primeira condição é confiar que isso é possível. Assim, está condenada, antes de tudo, a renúncia criticista. Para Hegel, a confiança deve animar o trabalho reflexivo da paciente e gradual apreensão do saber absoluto. Na época de Hegel, a reflexão negativa do criticismo havia acarretado, até mesmo, o repúdio da reflexão em vista do mero sentimento ou da simples opinião, não precisando mais expor nada à transparência do conceito. Em relação a isso, Hegel tenta reintroduzir no mundo filosófico o valor da razão que, embora nem sempre sob ataque direto, tem visto seus flancos minados através de periódicas insinuações, fazendo com que a humanidade seja, de tempos em tempos, governada por outras forças que não as racionais. Ou seja, com a razão sendo posta de lado, ocorreu a autorização de se falar e decidir tão somente com base, por exemplo, no sentimento e na opinião, principalmente quando se tratava de objetos religiosos.

\begin{tabular}{|l|l|l|l|l|}
\hline Qexista Dialectus & Ano 2 & n. 4 & Janeiro-Junho 2014 & p. 39-62 \\
\hline
\end{tabular}


Mas, Hegel, diferente de Kant, defende que a filosofia não é senão o exame da verdade também quando trata de objetos religiosos. Para Hegel, a filosofia não deve e não pode ser posta de lado na religião, pois, para ele, é uma afirmação equivocada que sobre a religião absolutamente não há que pensar; que a religião é simplesmente coisa do coração, em que a gente pode, e mesmo deve, com razão, privar-se da razão. Para o autor, é um erro representar as duas de modo que se excluam uma e outra ou como sendo separáveis. Ou seja, em Hegel, a religião e a filosofia não são opostas nem separáveis. Conforme Hegel, o sentimento religioso não é manchado, pervertido ou aniquilado pela razão. Mas, bem pelo contrário, ele pregava que ninguém deveria se contentar em aceitar uma doutrina religiosa sem antes tentar compreendê-la e justificála racionalmente. Para ele, qualquer doutrina, para que seja aceita, deve ser autenticada pela reflexão da pessoa, não recebida, por exemplo, com base na mera autoridade da Igreja. A filosofia, portanto, não se opõe abstratamente à religião, quando essa se realiza em sua verdade, que é apreender o conteúdo absoluto. Para Hegel, a filosofia sabe que não pode deixar de ter em vista essa forma absoluta de experiência, que é a religião.

\section{A dualidade crer - saber ou religião - filosofia}

Um dos problemas centrais, talvez até mesmo o central, do pensamento de Hegel é a dualidade crer - saber ou, dito de outro modo, religião (teologia) - filosofia na consciência humana e a respectiva transposição dela. Ou seja, inquietava a Hegel, como a poucos, a ideia da impossibilidade do conhecimento do [saber] absoluto, sustentada, por exemplo, por Kant. Como Hegel alimentava a fé de que o saber absoluto podia ser apreendido, sofre inquieto e insatisfeito, enquanto não consegue dar forma à visão absoluta de tudo desde o todo. Ora, segundo Hegel, o princípio da liberdade não reinaria enquanto o infortúnio e a irracionalidade da história não tiverem sido dissipados, enquanto a razão não se tornar soberana do tempo ${ }^{2}$.

\footnotetext{
2 Cf. BOURGEOIS, 1995, p. 412: "Na Fenomenologia do Espírito, resumem-se em particular as meditações hegelianas sobre o problema político, que será o centro das preocupações de Hegel enquanto a infelicidade e a desrazão não tiverem sido dissipadas, enquanto a razão não se tiver tornado mestra do tempo, ou seja, enquanto ela não o tiver ultrapassado como um de seus momentos. Finalmente, já que o que existe é a unidade do uno (o ideado) e do múltiplo (o real), já que a unidade se impõe sobre o múltiplo, a ideia sobre a realidade, a filosofia sobre a história, a reflexão de Iena culminará na afirmação de que a liberdade e a felicidade só têm seu ser no elemento da idealidade filosófica, que coroará a futura Enciclopédia." Ver também BOURGEOIS, 2000, p. 69.
}

\begin{tabular}{|l|l|l|l|l|}
\hline Qevista Dialectus & Ano 2 & n. 4 & Janeiro-Junho 2014 & p. 39-62 \\
\hline
\end{tabular}


Hegel defendia que o homem pode e, de certa forma, deve julgar-se digno de tudo quanto há de mais sublime. Ora, nada mais sublime do que a própria verdade toda e absoluta.

A Ideia, como unidade da ideia subjetiva e da objetiva, é o conceito da Ideia, para o qual a ideia como tal é o objeto; para o qual o objeto é ela: um objeto em que vieram reunir-se todas as determinações. Essa unidade é, pois, a verdade toda e absoluta, a ideia que se pensa a si mesma, e decerto aqui, enquanto ideia pensante, enquanto ideia lógica (HEGEL, 1995¹, §236, p. 366).

Ideia, como podemos ver, é a verdade toda e absoluta, e apenas uma via racional é capaz de levar a ela. Para vir a ter acesso à verdade ou ao saber absoluto, Hegel mostrou a existência e a necessidade de se percorrer todo um caminho ou realizar todo um processo através de uma série de experiências da consciência. Isto é, Hegel apresenta todo o esboço dos encadeamentos que dão conta do processo dialéticoespeculativo de tomada de consciência do saber absoluto, o qual recupera no conceito a sequência temporal das formas de cultura e as eleva à consciência universal.

Sobre isso, convém saber qual é a definição hegeliana de filosofia (Philosophie), pois, inclusive, ele a intitula como a ciência especulativa (spekulative Wissenschaft). Além disso, cabe conhecer qual é o método (Methode), o conteúdo (Inhalt) e a forma (Form), para Hegel, da demonstração científica (wissenschaftliche Beweise), já que, em Hegel, o conhecimento especulativo (spekulative Erkenntnisweise) ou o saber especulativo (spekulative Wissen) se distingue de qualquer outro modo de conhecimento (anderer Erkenntnisweise). Tal declaração é importante, uma vez que Hegel afirma que era necessário arrancar a filosofia da vergonhosa decadência (schmähliche Verfall), na qual se achava em sua época (Zeit). Segundo Hegel, o manifesto desprezo e descrédito (mannigfaltige Verachtung und Mißkredit) diante da filosofia decorriam, sobretudo, da crença de que o conhecimento da verdade (Erkenntnis der Wahrheit) seria uma tentativa insensata (törichte Versuch), pois se afirmava que o ser humano não pode conhecer o que é verdadeiro (der Mensch das Wahre nicht erkennen könne) ou, então, que o verdadeiro mesmo não pode ser conhecido (das Wahre selbst nicht erkannt werden könne). Ora, em função disso, a degradação (Degradation) da filosofia se fez tamanha que supostos filósofos, tal como J. F. Fries, segundo Hegel, não fundamentavam a ciência (Wissenschaft) no desenvolvimento do pensamento e do conceito (Entwicklung des Gedankens und Begriffs), com base na razão (Vernunft); mas, antes, assentavam a ciência apenas na percepção imediata (unmittelbare Wahrnehmung) e na imaginação acidental (zufällige Einbildung), baseando-se somente no coração (Herz), no ânimo

\begin{tabular}{|l|l|l|l|l|}
\hline Qexista Dialectus & Ano 2 & n. 4 & Janeiro-Junho 2014 & p. 39-62 \\
\hline
\end{tabular}


(Gemüt) e no entusiasmo (Begeisterung) para ponderar, por exemplo, sobre os objetos éticos, tal como o conceito de Estado. Contudo, para Hegel, a tarefa da filosofia (die Aufgabe der Philosophie) é conceituar ou apreender (begreifen) o que é (was ist). Ora, tudo que é, segundo Hegel, é conceituável (begreiflich) pelo pensamento. Mas, afinal, o que torna possível que a verdade (Wahrheit) ou o saber absoluto (absolutes Wissen) seja, em Hegel, conceituável, objeto da faculdade de compreensão (Begriffsvermögen)? Ora, cabe saber que a filosofia hegeliana, através do dito lado especulativo ou positivamente racional, busca unir o lado abstrato ou do entendimento e o lado dialético ou negativamente racional, suprassumindo-os ao conhecimento racional. É necessário conhecer tais elementos, dada a sua importância para compreender porque a filosofia é a história (Geschichte) de busca da apreensão do absoluto. Eis, enfim, para Hegel, a tarefa (Aufgabe) da filosofia.

Para Hegel, porém, o saber absoluto não é algo que se apreende de uma vez, em sua origem, mas é fruto de longo engendramento, que se eleva das formas inferiores para as superiores. Ora, a sucessão das formas ou dos muitos fenômenos da consciência, até que se chegue à consciência do saber absoluto, é o tema da Fenomenologia do Espírito ou da assim chamada "ciência da experiência da consciência", título que apresenta a proposta do escrito.

Na Fenomenologia do Espírito, em síntese, Hegel procurou analisar as etapas ou os momentos pelos quais o espírito tem de passar para poder compreender o saber absoluto. Mas, para que isso se efetive, deverá passar pela sucessão espiritual, a saber: a consciência, a autoconsciência (consciência de si), a razão, em suas diferentes figurações, em busca de sua suprassunção nas formas próprias do espírito (Geist), unido ao espírito do povo (Volksgeist), do espírito do tempo (Zeitgeist) e do espírito do mundo (Weltgeist), que se efetivam na história. Trata-se da marcha do espírito (Gange des Geistes) em prol do desenvolvimento do espírito (geistigen Entwicklung).

\footnotetext{
O que esta "Fenomenologia do Espírito" apresenta é o vir-a-ser da ciência em geral ou do saber. O saber, como é inicialmente - ou o espírito imediato - é algo carente-de-espírito: a consciência sensivel. Para tornar-se saber autêntico, ou produzir o elemento da ciência que é seu conceito puro, o saber tem de se esfalfar através de um longo caminho. (...) A tarefa de conduzir o indivíduo, desde seu estado inculto até o saber, deve ser entendida em seu sentido universal, e tinha de considerar o indivíduo universal, o espírito consciente-de-si na sua formação cultural (HEGEL, 2002, p. 40-41).
}

O saber absoluto, por assim dizer, não é, portanto, a apreensão de algo externo por um sujeito, mas a representação de um objeto por um sujeito é, ao mesmo tempo, parte integrante do objeto. Ou seja, não se pode falar de conhecimento, enquanto

\begin{tabular}{|l|l|l|l|l|}
\hline Qevista Dialectus & Ano 2 & n. 4 & Janeiro-Junho 2014 & p. 39-62 \\
\hline
\end{tabular}


determinada representação que um sujeito qualquer tem de algo situado absolutamente fora dele, pois isso significaria dizer que o conhecimento poderia ser verdadeiro encontrando-se fora do absoluto, isto é, da verdade. Assim sendo, a certeza que um sujeito tem do objeto é também uma experiência, na qual o sujeito aparece para si mesmo como fundador e carregador da verdade do dito objeto. A verdade do objeto passa a estar, ao mesmo tempo, dentro do discurso do sujeito. Ou seja, o discurso do sujeito, além de ser o local em que a verdade sobre algo aparece, também é o lugar em que o sujeito aparece a si mesmo. O discurso torna-se uma forma de constatação do próprio sujeito perante si mesmo. Compreende-se, assim, trazendo para a consciência tais experiências.

O caminho rumo ao saber absoluto exige, portanto, que encaremos a realidade como um todo e que tomemos consciência que somos parte integrante dessa mesma realidade. Ora, "o homem chega às coisas pela consciência que delas tem" (ROSENFIELD, 2002, p. 180). Por isso, em Hegel, todo ser humano deveria buscar e chegar a ser consciente de si mesmo, consciente de sua realidade e dignidade humanas, até porque é nisso que ele difere essencialmente dos demais animais, que não ultrapassam o nível do simples sentimento de si mesmo ${ }^{3}$.

Hegel declara, como já vimos, a necessidade de percorrer todo um caminho para apreender o saber absoluto, indicando a impossibilidade de uma intuição direta. Dito de outro modo, a necessidade de uma exposição do conhecimento, através da análise da série de experiências da consciência é o atestado da impossibilidade de um acesso imediato, intuitivo, ao saber absoluto.

Hegel justifica a sua crença na possibilidade de apreensão do saber absoluto, em função da existência do lado "especulativo ou positivamente racional" do pensamento, o qual "apreende a unidade das determinações em sua oposição: o afirmativo que está contido em sua resolução e em sua passagem [a outra momento]” (HEGEL, 19951, §82, p. 166). Trata-se do terceiro momento ou lado do pensar, antecedido pelo "pensar enquanto entendimento", que "fica na determinidade fixa e na diferenciação dela em relação a outra determinidade", e pelo "momento dialético", que "é o próprio suprassumir-se [suspender-se - Sichaufheben] de tais determinações finitas e seu

\footnotetext{
${ }^{3}$ Cf. KOJÈVE, 2002, p. 11: "O homem é consciência-de-si. É consciente de si, consciente de sua realidade e de sua dignidade humanas. É nisso que difere essencialmente do animal, que não ultrapassa o nível do simples sentimento de si. (...) O Ser do homem, o Ser consciente de si, implica e supõe o desejo. A realidade humana só se pode constituir e manter no interior de uma realidade biológica, de uma vida animal. Mas, se o desejo animal é condição necessária da consciência-de-si, não é condição suficiente".
}

\begin{tabular}{|l|l|l|l|l|}
\hline Qevista Dialectus & Ano 2 & n. 4 & Janeiro-Junho 2014 & p. 39-62 \\
\hline
\end{tabular}


ultrapassar para suas opostas” (Idem, §80, p. 159). Ou seja, o momento especulativo, para Hegel, é aquele que, frente a uma aparência de contradições inconciliáveis, obra do entendimento, relaciona tais determinações com os seus opostos, obra do momento dialético, negando-as, em parte, conservando-as, em outra, e elevando-as, por fim, ao que é positivamente racional. Por isso, em Hegel, a multiplicidade da realidade não impede o saber racional: "de modo algum que o racional seja a considerar em geral como inacessível e inconcebível para o pensar” (Idem, §82 Z, p. 169).

\section{O constante trabalho de busca da compreensão do saber absoluto}

Ora, Hegel é da ideia de que todo homem, a serviço da verdade, não deverá hesitar em pôr de lado qualquer opinião, mesmo que ela se lhe tenha tornado muito cara, pois, tal como defendia Aristóteles, é um dever de consciência dar preferência à verdade. O bom filósofo é aquele que, embora não abra mão tão logo de suas convicções pessoais, é capaz de se expor ao legado de qualquer autor que acaso esteja analisando.

Hegel, além disso, concorda com a ideia de que não há propriamente saber absoluto, se por saber absoluto entendermos uma regra, lei ou evidência exteriores ao próprio saber. Pois, para Hegel, o saber absoluto não é um saber atemporal e, também, não é um saber que possa ser denominado como perfeito, definitivo e irreformável, mas sempre está relacionado com o seu respectivo tempo histórico. Ora, eis em suma porque sempre estamos ou devemos estar em alerta para filosofar, pois a filosofia nunca se realiza definitivamente, mas, de forma contínua e, a princípio, gradativa, está sempre sendo considerada.

Em Hegel, "possuir o oposto na unidade e a unidade na oposição, eis o saber absoluto, e a ciência consiste precisamente em conhecer esta unidade, no seu pleno desenvolvimento, através dele mesmo" (HEGEL, 1974, p. 176). Ora, vários intérpretes procuram analisar tal elemento da filosofia hegeliana. Entre eles, cabe citar, primeiro, a afirmação de Lima Vaz:

O texto sobre o saber absoluto constitui o último capítulo da Fenomenologia do Espírito e é, notoriamente, uma das páginas mais densas e de mais difícil interpretação da obra hegeliana. Não sendo aqui o lugar para que se empreenda sua exegese minuciosa, podemos afirmar, em todo caso, que não se trata desse saber esotérico ou dessa onisciência divina que autores respeitáveis, com toda a seriedade, julgam ter Hegel reivindicado para si. O saber absoluto pode ser caracterizado, em primeira aproximação, como o saber que recupera no conceito a sequência temporal das experiências da consciência (ou das formas de cultura) e eleva a consciência individual à

\begin{tabular}{|l|l|l|l|l|}
\hline Qevista Dialectus & Ano 2 & n. 4 & Janeiro-Junho 2014 & p. 39-62 \\
\hline
\end{tabular}


consciência universal ou efetivamente racional (LIMA VAZ, 1995, p. 236).

E, em segundo lugar, a afirmação de Paulo Meneses:

\begin{abstract}
O saber absoluto recapitula e enfeixa todos os momentos e figuras anteriores, que na verdade são as etapas de seu vir-a-ser. O movimento é o da reconciliação da consciência com a consciência de si, da objetividade e do si: reconciliação que já ocorreu na religião, embora no elemento da representação. Agora se passa para o elemento do conceito: o que era apenas em si, vem também a ser para a consciência, como seu próprio agir e seu próprio saber (MENESES, 2003, p. 62).
\end{abstract}

Se, contudo, não há esse saber absoluto, como dito acima, não se segue que não haja nada de absoluto no saber, porque há, ao menos, a exigência da busca do saber absoluto que, em e por si, dá sentido à filosofia. Do mesmo modo, poder-se-á dizer que, em certo sentido, não há resposta na metafísica, se por resposta entender-se uma solução que dispensasse de refletir mais apuradamente, de reexaminar as razões e de apresentálas sempre para o debate. As ciências exatas, até certo ponto, comportam algumas soluções que suprimem a questão. Mas, a metafísica é praticamente uma interrogação permanente. No mais das vezes, a própria solução, no momento subsequente, já é um problema e incita à pesquisa. Longe de pôr fim à questão, passa a outras questões e não pode valer senão sob a condição de se refazer, de forma gradativa, um tanto quanto como se quase nada houvesse sido concluído. Por isso, para Hegel, tanto na religião quanto na filosofia ou nas demais ciências, como nas instituições efetivas, deve sempre haver o senso crítico para com tudo o que for objeto de consideração.

\title{
O conceito hegeliano de Estado e o de religião
}

No $§ 270$ A, da Filosofia do Direito, Hegel procura realizar minucioso exame sobre a relação entre Estado e religião. Ele o faz porque, no $\S 270$, havia procurado expor detalhes do conceito de Estado segundo a sua Ideia, tal que o "Estado sabe o que ele quer, e o sabe em sua universalidade, como algo pensado" (HEGEL, 2010, §270, p. 241). Para esclarecer, Hegel acaba proclamando que aquele era e deveria ser "o lugar de abordar a relação do Estado com a religião" (Ibidem), uma vez que a "determinação essencial sobre a relação entre religião e Estado obtém-se apenas à medida que se recorda seu conceito"; ora, em função do conceito, ele pode expressar a relevância de tal exame, pois a "religião tem por seu conteúdo a verdade", tal como o Estado, "com isso, recai nela também a mais elevada disposição de espírito" (Ibidem, p. 242). Isto é, em Hegel, a religião e o Estado têm por conteúdo a verdade, pois afirma: "É o

\begin{tabular}{|l|l|l|l|l|}
\hline Qexista Dialectus & Ano 2 & n. 4 & Janeiro-Junho 2014 & p. 39-62 \\
\hline
\end{tabular}


discernimento filosófico que conhece que Igreja e Estado não estão em oposição quanto ao conteúdo da verdade e da racionalidade, mas numa diferença de forma" (Ibidem, p. 249).

No $§ 552 \mathrm{~A}^{4}$ da Enciclopédia, Hegel também anuncia: "Este é o lugar de aprofundar a relação do Estado e da religião, e de elucidar as categorias que estão em voga a respeito" (HEGEL, 1995², §552 A, p. 328), e, na sequência, novamente afirma que "a religião como tal, assim como o Estado como tal, enquanto formas em que existe o princípio [sabedor de sua essência], contém neles a verdade absoluta de modo que esta, enquanto é como a filosofia, está ela mesma somente em uma de suas formas" (Ibidem, p. 336). Ora, Hegel expõe tais análises no âmbito da Filosofia do Espírito Objetivo, ao tratar, de modo particular, da Eticidade (Sittlichkeit) e do espírito do povo (Volksgeist). Ora, sobre isso, convém destacar que Estado e religião concorrem juntos para formar os princípios da vida ética, não só, mas de modo relevante e decisivo.

\section{A doutrina do Estado e a doutrina da religião em Hegel}

$\mathrm{Na}$ medida em que o Estado e a religião têm por conteúdo a verdade, Hegel afirma que não deveria haver propriamente oposição entre as esferas estatal e religiosa. Ora, isso porque, para Hegel, a relação entre Estado e religião, ou entre a consciência estatal e a consciência religiosa, deveria ser de equilíbrio uma com a outra, conservando cada uma sua autonomia. Ou seja, não deveria haver nem imperialismo religioso nem político, mas deveria imperar a liberdade. Isto é, nenhuma das partes deveria propriamente impor sua doutrina sobre a outra, pois a religião não deveria ser decretada pelo Estado, como tampouco o Estado pela religião, mas cada qual deveria apreender a verdade. Ora, Hegel acredita e prega que as doutrinas da religião e do Estado podem e, de certo modo, devem vir a se harmonizar. Ou seja, na medida em que eles têm em vista o mesmo objeto, Hegel espera que ambos apreendam e externalizem a verdade, em especial, todas as determinações do princípio da liberdade.

Inclusive, enquanto o princípio da liberdade não estiver em voga na religião, segundo Hegel, não pode vir a haver uma Constituição racional, pois uma religião, que porventura se oponha às leis racionais, facilmente inviabiliza a disposição subjetiva para

\footnotetext{
${ }^{4}$ Segundo B. Bourgeois (1995, Nota 8, p. 334), a anotação do § 552, envolvendo a relação do Estado e da religião, não existe enquanto tal em 1817; em 1827, a anotação é acrescentada, mas sua exposição difere da de 1830 , pois esta, em síntese, congrega além do texto da anotação do $§ 552$, também o da anotação do $\S 563$, de 1827 .
}

\begin{tabular}{|l|l|l|l|l|}
\hline Qevista Dialectus & Ano 2 & n. 4 & Janeiro-Junho 2014 & p. 39-62 \\
\hline
\end{tabular}


a obediência à lei. Ora, para Hegel, com uma religião da não-liberdade, sobretudo em sua época, seria abstrato e vazio imaginar a possibilidade de que os indivíduos ajam segundo o sentido ou a letra da lei e não segundo o espírito da religião, na qual reside, no mais das vezes, sua consciência moral mais íntima ou sua obrigação suprema ${ }^{5}$.

Por isso, Hegel examina a história das religiões e critica as religiões da nãoliberdade, que não mais respondem às exigências do novo tempo. Para ele, há uma imbricação essencial entre o desenvolvimento da história estatal e religiosa, pois a religião não sendo da liberdade torna inviável o Estado da liberdade. Ora, o Hegel da Fenomenologia do Espírito, da Ciência da Lógica, da Enciclopédia, da Filosofia do Direito, da Filosofia da Religião, da Filosofia da Estética, da História da Filosofia ou, ainda, o da Filosofia da História, é sempre o mesmo filósofo preocupado com a liberdade dos seres humanos. A sua filosofia desvela a emergência da consciência da liberdade, a qual é o fundamento de toda a ação política ${ }^{6}$. Mas, por isso, segundo Hegel, deve haver a consolidação do desenvolvimento do princípio da liberdade, em especial, na religião. A religião que reconcilia, que religa, a religião em sua verdade, para Hegel, é tão somente a religião da liberdade. $\mathrm{O}$ exame da religiosidade levou-o a proclamar a necessidade de transformação das religiões da não-liberdade, que consagram, por exemplo, o despotismo, para que se dê a instauração só de religiões da liberdade.

Contudo, na medida em que o objeto é comum, Hegel também admite que uma Igreja e um Estado possam vir a estar em oposição um ao outro. Não quanto ao lado ainda interno da representação da consciência religiosa e estatal, mas quando da externação das suas doutrinas, pois "Estado e Igreja se encontram aqui diretamente em acordo ou em oposição" (HEGEL, 2010, §270 A, p. 248). Ou seja, a doutrina de uma Igreja normalmente não é algo meramente interno, da esfera da consciência moral, mas,

\footnotetext{
5 Cf. HEGEL, 1995², §552, p. 332-333: “De nada serviria que as leis e a ordem pública fossem transformadas em uma organização racional de direito, se o princípio da não-liberdade não for abandonado na religião. Os dois são incompatíveis entre eles: é uma representação tola querer assinalar a ordem pública e à religião um domínio separado, na suposição de que sua diversidade se comportaria tranquilamente, na relação de um termo para com o outro, e não rebentaria em contradição e luta (...) é somente uma representação abstrata, vazia, simular como possível que os indivíduos só atuem conforme o sentido ou a letra da legislação, e não segundo o espírito de sua religião, em que residem sua consciência mais íntima, e sua obrigação suprema. As leis aparecem, nessa oposição contra o que é declarado santo pela religião, como algo feito pelos homens; mesmo se fossem sancionadas e exteriormente estabelecidas, não poderiam oferecer resistência durável à contradição e aos ataques do espírito religioso contra elas. Fracassariam assim tais leis, mesmo que seu conteúdo fosse verdadeiro, na consciência cujo espírito difere do espírito das leis e não as sanciona. Deve-se julgar uma insensatez dos tempos modernos mudar o sistema de uma eticidade corrompida, sua constituição e legislação, sem a mudança da religião; ter feito uma revolução, sem uma reforma; imaginar que, com a velha religião e suas santidades, uma Constituição política a ela oposta poderia ter em si tranquilidade e harmonia”.

6 “A emergência do mundo moderno significou a afirmação da liberdade enfim realizada, tanto em sua dimensão subjetiva, como na sua dimensão objetiva” (HELFER, 1991, p. 287).
}

\begin{tabular}{|l|l|l|l|l|}
\hline Qexista Dialectus & Ano 2 & n. 4 & Janeiro-Junho 2014 & p. 39-62 \\
\hline
\end{tabular}


enquanto doutrina, pode vir a ser também externalizada. Daí decorre a possibilidade do conflito, pois o Estado igualmente tem uma doutrina a ser externalizada. Portanto, as doutrinas da Igreja e do Estado, quando externalizadas, ao invés de harmônicas, podem ser diversas e, até mesmo, ser opostas. Diante disso, procurando encaminhar qualquer conflito futuro, Hegel afirma que, quanto à externação, no âmbito do Espírito Objetivo, toda doutrina da religião pode vir a passar imediatamente para o domínio da doutrina do Estado. Mas, por quê? Inclusive, por que não o inverso?

\section{A supremacia da doutrina estatal em relação à doutrina religiosa}

Como vimos, em Hegel, tanto a religião quanto o Estado buscam apreender a verdade, contudo, afirma que cada uma delas tem uma forma própria ou específica de apreendê-la. Eis, como ele o expressa: "é o discernimento filosófico que conhece que Igreja e Estado não estão em oposição quanto ao conteúdo da verdade e da racionalidade, mas numa diferença de forma" (Ibidem, p. 249). Ora, antes de maiores esclarecimentos sobre o que é tal diferença de forma, convém ressaltar que ela é muito importante, pois Hegel a estrutura como critério determinante para estabelecer se a religião (Igreja) passa ou não para o domínio do Estado, no âmbito do Espírito Objetivo, diante de um conflito quando da externação das suas doutrinas. Além disso, cabe destacar que a doutrina de uma Igreja, segundo Hegel, até pode ser algo meramente interno (Innere), onde não compete ao Estado imiscuir-se; contudo, normalmente se

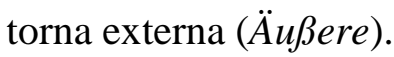

A doutrina da Igreja não é somente algo interno da consciência moral, porém
é antes, enquanto doutrina, externação e, ao mesmo tempo, externação a
respeito de um conteúdo que se liga, da maneira mais íntima, com os
princípios éticos e as leis do Estado ou que lhes concerne mesmo
imediatamente. Portanto Estado e Igreja se encontram aqui diretamente em
acordo ou em oposição (Ibidem, p. 247-248).

Diante da externação (Äußerung), o Estado e a Igreja encontram-se, diretamente, em acordo (zusammen) ou, então, em oposição (gegen), porque, tal como a religião, também é característico de todo Estado particular ter a sua própria doutrina externalizada.

O Estado também tem uma doutrina, visto que suas instituições e o que, em geral, vale para ele a respeito do direito, da constituição etc. estão essencialmente enquanto lei na forma do pensamento, e visto que ele não é nenhum mecanismo, porém a vida racional da liberdade autoconsciente, o sistema do mundo ético, assim a disposição de espírito e logo a consciência da mesma nos princípios são um momento essencial no Estado efetivo (Ibidem, p. 247).

\begin{tabular}{|l|l|l|l|l|}
\hline Qevista Dialectus & Ano 2 & n. 4 & Janeiro-Junho 2014 & p. 39-62 \\
\hline
\end{tabular}


Assim sendo, "quando a Igreja passa ao ensinamento [doutrinal] (...) e quando seu ensinamento concerne aos princípios objetivos, aos pensamentos do ético e do racional, assim ela passa imediatamente nessa externação para o domínio do Estado" (Ibidem, p. 249-250). Isto é, no âmbito do Espírito Objetivo, em caso de conflito, prevalece a doutrina do Estado sobre a doutrina da religião ou Igreja, a qual, enquanto instituição, serve de exemplo para as demais relações institucionais. Tudo porque como podemos observar abaixo, Hegel apresenta uma distinção conceitual determinante.

O Estado sabe o que ele quer, e o sabe em sua universalidade, enquanto algo pensado; por causa disso, ele atua e age segundo fins conscientes, segundo princípios conhecidos e segundo leis que não são apenas em si, porém para a consciência; e igualmente, à medida que suas ações se vinculam com as circunstâncias e as relações presentes, ele atua e age segundo o conhecimento determinado das mesmas (Ibidem, p. 241).

A religião, em contrapartida, acabou tendo outra apreciação por Hegel.

O Estado, em geral, sabe seus fins, conhece-os e os realiza com uma consciência determinada e segundo princípios. Como se notou acima, a religião tem, então, o verdadeiro por seu objeto universal, contudo, enquanto um conteúdo dado, que não é conhecido em suas determinações fundamentais mediante o pensamento e o conceito; igualmente a relação do indivíduo com esse objeto é uma obrigação fundada numa autoridade, e o testemunho do espírito e do coração próprios, na medida em que é aquilo em que o momento da liberdade está contido, é fé e sentimento (Ibidem, p. 249).

Ou seja, segundo Hegel, o Estado e a religião apresentam uma diferença relevante no interior da consciência, propriamente na forma de apreensão, a qual determina a supremacia da doutrina do Estado em relação à da religião. Ora, em contraste com a religião, "com a fé", "com a sua convicção subjetiva", de acordo com Hegel, "o Estado é antes o que sabe"; pois "em seu princípio, essencialmente, o conteúdo não permanece na forma do sentimento e da fé, porém pertence ao pensamento determinado" (Ibidem, p. 250). Com isso, o autor apresenta o que considera a distinção e semelhança entre Estado e religião.

\section{A forma de apreensão religiosa, estatal e filosófica da verdade}

Mas, para compreender os aspectos acima enumerados, cabe ressaltar que, para Hegel, também "o conteúdo da filosofia e da religião é o mesmo" (HEGEL, 1995², $\S 573$, p. 352). Ou seja, igualmente a filosofia e a religião apresentam, sob formas diferentes, o mesmo conteúdo (Inhalt), a saber, a verdade; tal como o Estado e a

\begin{tabular}{|l|l|l|l|l|}
\hline Qevista Dialectus & Ano 2 & n. 4 & Janeiro-Junho 2014 & p. 39-62 \\
\hline
\end{tabular}


religião ${ }^{7}$. Por isso, para Hegel, o Estado e a filosofia se desenvolvem, igualmente, a partir da religião ${ }^{8}$ e, conforme o "princípio do espírito sabedor de sua essência (...), é que está presente a absoluta possibilidade [Möglichkeit] e necessidade [Notwendigkeit] de que coincidam, em um só, o poder do Estado, a religião e os princípios da filosofia"; isto é, "de que se cumpra a reconciliação da efetividade, em geral, com o espírito; do Estado com a consciência religiosa e, igualmente, com o saber filosófico" (Ibidem, §552 A, p. 336). Ou seja, a verdade, portanto, deve encontrar-se nos Estados, para constituílos e orientá-los. Ora, Hegel, inclusive, ressalta que Platão apreendeu a verdade sob a forma da filosofia e, por isso, acabou afirmando que "enquanto os filósofos não governarem nos Estados, ou os que no presente se chamam reis e soberanos não filosofarem de maneira profunda e abrangente, não haveria, para os Estados, libertação dos males nem tampouco para o gênero humano"; em outras palavras, ele afirma que "todo cidadão tem possibilidade de acesso a cargos estatais; todavia, talento e habilidade são condições indispensáveis", pois "os sábios devem governar; não a ignorância" (HEGEL, 1999, p. 372-373). Mas, para Hegel, "não foi permitido a Platão poder avançar a ponto de dizer que, enquanto a verdadeira religião não surgisse no mundo e não se tornasse dominante nos Estados, o princípio verdadeiro do Estado não chegaria à efetividade" (HEGEL, 1995², §552, p. 335); pois, “enquanto esse princípio não pôde chegar ao pensamento, não podia a Ideia verdadeira do Estado ser apreendida pelo pensamento" (Ibidem, p. 335-336).

Segundo Bourgeois $\left(1970^{2}\right.$, p. 118), trata-se, por exemplo, da crítica hegeliana ao "Estado judaico como Estado religioso no qual os comandos de Deus têm lugar de constituição política". Para Hegel, deve haver uma distinção concreta entre a esfera estatal e a esfera religiosa.

\section{A distinção entre consciência religiosa, estatal e filosófica}

Ora, na Introdução à Enciclopédia, Hegel expõe a diferença da representação religiosa do absoluto, que se move na exterioridade da representação (exterioridade

\footnotetext{
${ }^{7}$ Cf. BOURGEOIS, $1970{ }^{1}$, p. 130, Nota 52, prefácio da $2^{\mathrm{a}}$ edição [TP]: "Tema maior do hegelianismo: religião e filosofia têm o mesmo conteúdo, mas a religião o apresenta na forma da representação (pensamento cujo conteúdo é ainda tomado na exterioridade), enquanto que a filosofia o apresenta na forma do conceito (pensamento puramente interior, imanente a ele-mesmo, "em si" nas suas determinações, livre)".

${ }^{8}$ Cf. HEGEL, $1995^{2}$, § 552 A, p. 335: "O Estado, que se desenvolve igualmente - porém mais cedo do que a filosofia - a partir da religião".
}

\begin{tabular}{|l|l|l|l|l|}
\hline Qevista Dialectus & Ano 2 & n. 4 & Janeiro-Junho 2014 & p. 39-62 \\
\hline
\end{tabular}


interna do conteúdo da revelação e exterioridade externa de sua recepção pelo crente), em relação à apreensão que se dá na filosofia, que, para Hegel, desdobra e engendra o processo de autodeterminação a si mesmo, que é o conceito. A “diferença está ligada [ao fato de] que o conteúdo humano da consciência, fundado graças ao pensar, não aparece primeiro na forma de pensamento, mas como sentimento, intuição, representação" (HEGEL, 1995, §2, p. 40).

A diferença entre a filosofia e a religião não é de modo algum a diferença entre entendimento e sentimento, e sim a de um pensamento conceitual - que tira suas determinações do movimento imanente de diferenciação, e a de um pensamento representativo, que recebe suas determinações da exterioridade de uma revelação (BOURGEOIS, 1995, p. 413).

Ora, a forma de apreensão da religião é distinta da forma da filosofia, pois ela não tem como elemento próprio a "expressão conceitual do conceito" ou a "apresentação especulativa do especulativo", , pois Hegel apregoa que pertence à fé (a religião) o conteúdo (a verdade), não na forma do conceito, mas da mera representação ${ }^{10}$. Ou seja, “concebe a articulação da religião na forma da representação (...). Em outras palavras, a representação é a maneira pela qual aparece a verdade absoluta na religião" (AQUINO, 1989, p. 276). Assim sendo, a religião, do ponto de vista da consciência, até apreende a verdade pela fé, mas não a suprassume ao nível do conceito.

\begin{abstract}
A religião tem, por conseguinte, um conteúdo comum com a filosofia, só as formas são diversas: importa somente que a forma do conceito alcance uma perfeição tal que seja capaz de apreender o conteúdo da religião. (...) Não para suplantar a Igreja, mas para se conciliar com a Igreja. A filosofia, enquanto pensamento que compreende este conteúdo, tem, a respeito das Ideias da religião, a vantagem de compreender ambas as partes: isto é, compreende a religião (...) e, além disso, compreende-se a si mesma. Muitas vezes temos razão, quando censuramos a filosofia por se opor à religião; mas também muitas vezes a tratamos com injustiça, quando essa censura é feita do ponto de vista religioso (HEGEL, 1974, p. 132 e 134).
\end{abstract}

Portanto, para Hegel, a doutrina religiosa sempre permanece no domínio do mistério, ou seja, na diferença entre a subjetividade religiosa e a objetividade da verdade certificada na fé, ainda não consolidada no conceito. Segundo Hegel, a fé é sempre uma hipoteca da razão subjetiva carente de uma outra razão, garantia da certeza como

\footnotetext{
${ }^{9}$ BOURGEOIS, 1995, p. 415: "O debate entre filosofia e religião, que constitui o essencial dos Prefácios da Enciclopédia, dá ocasião a Hegel para justificar sua empresa, se o mistério é o racional ou o especulativo, o pensamento em sua verdade só existe na filosofia especulativa - apresentação especulativa do especulativo, expressão conceitual do conceito -, discurso que suprime toda contradição, oposição e alteridade, e realiza assim, em sua identidade concreta, o projeto sistemático ou enciclopédico".

${ }^{10}$ Cf. HEGEL, 2002, p. 367: "a fé possui, na verdade, seu conteúdo igualmente no elemento da pura consciência-de-si; mas no pensar, não no conceituar: na pura consciência, não na pura consciência-desi. (...) a essência da fé decai do pensar para a representação".
}

\begin{tabular}{|l|l|l|l|l|}
\hline Qexista Dialectus & Ano 2 & n. 4 & Janeiro-Junho 2014 & p. 39-62 \\
\hline
\end{tabular}


verdade $^{11}$. Ora, isso é o que, para Hegel, diferencia a religião da filosofia; pois, enquanto ciência, a filosofia hegeliana tem o mesmo elemento da forma que o Estado ${ }^{12}$, a saber, a forma do conceito. Portanto, o Estado e a religião, em Hegel, tal como a filosofia e a religião, diferem na sua forma de apreender a verdade; isto é, na filosofia e no Estado na forma do conceito, enquanto na religião como fé, ou seja, um saber em uma outra consciência. A fé, como verdade apreendida, mas não de todo suprassumida, coloca sempre uma outra consciência frente à sua consciência. Enfim, trata-se da distinção que perpassa a consciência religiosa e a real unidade consigo mesma da consciência filosófica ou estatal.

Assim, em Hegel, a doutrina de uma religião (Igreja) pode vir a ter que ceder em favor da do Estado, pois o Estado é aquele que sabe. Isto é, o Estado, segundo o conceito, é juiz das ações das Igrejas porque, para Hegel, no Estado a doutrina é racional. Assim, o Estado atua em plena consciência e é quem realmente constitui a organização da liberdade no nosso mundo. Ou seja, a supremacia do Estado se dá enquanto ele realiza soberanamente a razão ${ }^{13}$. Segundo Hegel, "no Estado tudo é sólido e assegurado, é o reduto contra o arbítrio e a opinião positiva"; ora, justamente, por isso, “a religião como tal não deve ser aquilo que governa” (HEGEL, 1998, §270 Z. p. 63).

Contudo, o Estado e a religião, segundo Hegel, na medida em que buscam o mesmo conteúdo, devem juntos, enquanto manifestações da razão, vir a promover a liberdade ${ }^{14}$. Isso, porém, não quer dizer que o tema da religião foi, em Hegel, um

\footnotetext{
${ }^{11}$ Cf. SCHNEIDER, 2003, p. 319: "Hegel fala da verdade que a religião ou a consciência religiosa subjetiva tem, mas na forma de "certeza", não do conhecimento e do conceito especulativo. É exatamente essa a diferença essencial entre religião e Filosofia: A religião alcança a verdade, com certeza, na fé, sem se elevar ao conceito especulativo (...) A fé é sempre uma hipoteca da razão subjetiva carente de intuição a uma outra Razão, garantia da certeza como verdade. "A fé possui o conteúdo (a verdade) sem intelecção" (PhG 379)".

${ }^{12}$ Cf. HEGEL, 2010, §270 A, p. 250-251: "a ciência também tem o seu lugar a seu lado; pois ela tem o mesmo elemento da forma que o Estado, ela tem o fim do conhecer e, de fato, da verdade objetiva pensada e da racionalidade".

${ }^{13}$ Cf. WEIL, 1985, p. 49-51 [TP]: "O Estado é juiz das ações da Igreja e das Igrejas porque ele pensa, porque ele sabe. É ele, e somente ele, que age em plena consciência. (...) A supremacia terrestre do Estado decorre de seu conteúdo espiritual: ele realiza soberanamente, pois realiza o espírito e a liberdade, "o valor infinito do indivíduo"."

${ }^{14}$ Cf. HEGEL, 1999, p. 283: "A tarefa, por conseguinte, é fazer com que a ideia do espírito também entre no mundo do presente espiritual e imediato. Sobre isso, ainda temos que observar um aspecto geral. Desde sempre se quis antepor a razão à religião, assim como a religião ao mundo. Observando-se mais de perto, vemos que esse antagonismo é só uma diferença. A razão é a essência do espírito, tanto do divino quanto do humano. A diferença entre religião e mundo é só que a religião como tal é a razão na alma e coração, o Estado, ao contrário, é um templo da liberdade humana no saber e no querer da realidade, cujo próprio conteúdo pode ser chamado de divino. Assim, a liberdade no Estado é preservada e confirmada pela religião, já que o direito moral no Estado é só a execução daquilo que constitui o princípio fundamental da religião. A tarefa da história é fazer a religião aparecer como razão humana, e
}

\begin{tabular}{|l|l|l|l|l|}
\hline Qevista Dialectus & Ano 2 & n. 4 & Janeiro-Junho 2014 & p. 39-62 \\
\hline
\end{tabular}


artifício estratégico a ocultar um pensamento político que, de outro modo, não poderia ter expressão ${ }^{15}$. Ora, a religião até serve aos propósitos de ordem moral, pois a religião forma-se como a "consciência da verdade e também a causa que faz o sujeito se ajustar", todavia, para Hegel, sua existência visa apenas “administrar o sagrado", pois quando se ela "se rebaixa ao temporal, este poder mostra-se de uma maneira desprezível, porque todas as paixões encontram justificativa" (HEGEL, 1999, p. 292293).

Assim, como vimos, para Hegel, a "religião é a espécie e a modalidade da consciência, segundo a qual a verdade é para todos os homens" (HEGEL, 1995, p. 25). Isto é, "a forma da religião é necessária ao espírito como é em si mesmo e por si mesmo; essa é a forma de verdade comum a todos os homens e a toda a forma de consciência" (HEGEL, 1974, p. 134). Mas, além disso, "é preciso compreender que o Estado foi constituído na religião. Estado e leis não são mais do que o surgimento da religião nas relações da realidade" (HEGEL, 1999, p. 346). Portanto, a religião, para Hegel, não é um estágio de consciência preliminar e, como tal, provisório do espírito, que encontraria sua expressão final na filosofia ou no Estado, mas são formas distintas de apreender a verdade, cada qual com seu valor.

\begin{abstract}
Mesmo a religião, sendo ela a mais nobre e santa, não deve ter nada que seja diferente da constituição estatal ou oposto a esta. A profunda sabedoria indica-nos que se deve distinguir as leis estatais, por uma parte, e a religião, por outra, já que se teme a simulação e a hipocrisia de uma religião estatal; todavia, mesmo quando religião e Estado são distintos na doutrina, na raiz buscam a mesma coisa, e as leis têm sua garantia suprema na religião (Ibidem, p. 367).
\end{abstract}

Por isso, Hegel afirma que é preciso declarar, terminantemente, que com uma religião da não-liberdade não é possível uma constituição racional, pois "governo e povo precisam ter, reciprocamente, esta última garantia da vontade interna, e só a podem ter numa religião que não se oponha à constituição do Estado racional" (Idem). Para Hegel, tanto seria "um escárnio se todo sentimento contra a tirania fosse recusado pelo fato de que o oprimido encontraria seu consolo na religião", quanto "esquecer que a religião pode adotar uma forma que tem por consequência a mais dura das servidões

fazer o princípio religioso que habita o coração dos homens também produzir a liberdade temporal. Assim se supera a desavença entre o interior do coração e a existência".

${ }^{15}$ Cf. OLIVEIRA, 1996, p. 50: "A problemática da religião, intimamente, ligada à problemática política, ao grande desafio de seu tempo: tornar a liberdade "realidade concreta", e isto não em virtude de uma politização da religião, mas por seu caráter enquanto religião. Religião é, para o Hegel tardio, a consciência do conteúdo absoluto, da verdade absoluta e sua função política, seu papel específico na sociedade e no Estado se fundamenta, precisamente, em sua especificidade, ou seja, o de ter a verdade absoluta como conteúdo".

\begin{tabular}{|l|l|l|l|l|}
\hline Qexista Dialectus & Ano 2 & n. 4 & Janeiro-Junho 2014 & p. 39-62 \\
\hline
\end{tabular}


sob as cadeias da superstição e da degradação do homem abaixo do animal" (HEGEL, 2010, §270 A, p. 242). Mas, em contrapartida, segundo Hegel, "a religião tem por seu conteúdo a verdade absoluta [Die Religion hat die absolute Wahrheit zu ihrem Inhalt] e, com isso, recai nela também a mais elevada [Höchste] disposição de espírito"; além disso, "a religião é o momento integrador do Estado para o mais profundo [Tiefste] da disposição de espírito" (Ibidem, p. 242 e 245); ou seja, "a religião contém também o lugar que, em todas as mudanças e na perda dos fins, dos interesses e das posses efetivos, concede a consciência do imutável e da liberdade e da satisfação supremas [höchsten Freiheit und Befriedigung]" (Ibidem, p. 242-243). Assim, em Hegel, "está na natureza da Coisa que o Estado cumpra uma obrigação de conceder à comunidade toda a sua assistência para seus fins religiosos e de lhe garantir proteção" (Ibidem, p. 245), pois o Estado deve promover a liberdade, inclusive, a religiosa. Para Hegel, todos precisam reconhecer que o Estado e a religião ocupam lugares de capital importância na vida humana. Mas, as autoridades estatais e as religiosas devem representar e secundar as aspirações de seu povo e se manter dentro dos limites de suas competências.

\section{O progresso histórico da e na consciência da Ideia de liberdade}

Em Hegel, a invariável exigência em prol do trabalho de efetivação da liberdade, ainda que, muitas vezes, para muitos, seja uma força silenciosa e obscura, encaminha os homens para a edificação de um mundo, que é de fato humano, na medida em que abre mais espaços de liberdade. Ou seja, só com a liberdade em voga, é possível a necessária reflexão sobre o sentido presente da ação histórica, a qual é prerrogativa essencial do autor histórico ou, dito de outro modo, de todo ser humano, sujeito da história. Sem tal consciência da liberdade, o ser humano seria apenas objeto de forças e de fatores heterônomos, anônimos ou, então, somente submetido à necessidade do instinto. Ora, “definido o conceito da filosofia, no sentido de pensamento que, como conteúdo geral, é o ser na sua totalidade, demonstrar-se-á na história da filosofia como as determinações se libertam pouco a pouco nos aspectos deste conteúdo" (HEGEL, 1974, p. 145). Por isso, Hegel define a história como sendo o progresso da e na consciência da Ideia de liberdade $^{16}$. Trata-se de uma definição que procura reunir alguns dos conceitos

\footnotetext{
16 A história é o progresso na consciência da liberdade, pois, para Hegel, o grau de liberdade que a humanidade atinge é sempre maior. Há, assim, em Hegel, três grandes períodos na história universal, a saber, o oriental, onde só um era livre (despotismo oriental), o grego e romano, onde alguns eram livres e, por fim, o cristão-germânico, onde todos são tidos como livres, do ponto de vista da Ideia.
}

\begin{tabular}{|l|l|l|l|l|}
\hline Qevista Dialectus & Ano 2 & n. 4 & Janeiro-Junho 2014 & p. 39-62 \\
\hline
\end{tabular}


fundamentais do Iluminismo ou Esclarecimento (Aufklärung) do século XVIII, do qual Hegel era filho, mas que ele pretendia, justamente, submeter a certa revisão crítica, bem profunda. A história é, pois, progresso, que se exprime em níveis de consciência e o objeto dessa consciência é a Ideia de liberdade.

Hegel viveu uma idade de revoluções, e o importante para ele era interpretar essas grandes transformações políticas, sociais e econômicas à luz da racionalidade profunda da história ou da emergência da liberdade. Para tanto, era necessário que o entrelaçamento dialético entre a consciência e o mundo histórico, ou entre as mediações subjetiva e objetiva, encontrasse seu sentido ou sua razão última num discurso que tematizasse formalmente essa inteligibilidade radical da história (LIMA VAZ, 1995, p. 237).

Em Hegel, o discurso da Filosofia da História sempre persegue o fio da racionalidade profunda que une todas as situações históricas, o qual se revela como a Ideia da liberdade.

A consciência chegou até aqui, e esse é o principal momento da forma na qual o princípio da liberdade se concretizou, pois a história universal nada mais é que o desenvolvimento do conceito de liberdade. (...) A filosofia diz respeito ao esplendor da Ideia que se reflete na história universal. (...) Seu interesse é conhecer o processo de desenvolvimento da verdadeira Ideia, ou seja, da Ideia da liberdade que é somente a consciência da liberdade (HEGEL, 1999, p. 373).

O Estado, para Hegel, enquanto Ideia, é racional, porque fala universalmente, para todos e para cada um, em suas leis, e todos e cada um encontram reconhecido, por suas leis, aquilo que forma o sentido, o valor e a dignidade de sua existência. Mas, podem igualmente existir Estados empíricos que sejam tirânicos, Estados injustos, Estados que, segundo Hegel, não tenham alcançado a etapa que corresponde ao "espírito

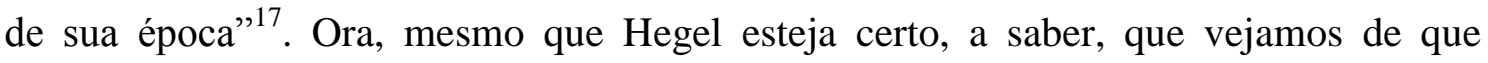
maneira tais Estados serão levados, ante o tribunal da história, a fim de serem condenados, cabe, no entanto, perguntar o que a religião (a Igreja ou as Igrejas), em questão, pode e/ou deve fazer no momento em que ocorrem, de forma empírica, tais circunstâncias?

Ora, Hegel afirma que a Igreja não deve se rebaixar aos assuntos políticos, pois eles são do âmbito ou da alçada do Estado. Mas, isso não quer dizer que a religião não possa ou não deva se importar e exigir o reconhecimento da cidadania de seus fiéis e de suas implicações, pois, só para dar um exemplo, uma religião da liberdade não deve jamais ficar omissa diante de ações contra a liberdade, nem partilhar de tal procedimento. Inclusive, quando Hegel prega a necessidade da fé ou da religião ser

\footnotetext{
${ }^{17}$ Cf. WEIL, 1985, p. 51 e 55 [TP]: "Estados que não tenham atingido a etapa que é aquela do espírito de sua época. (...) O Estado hegeliano é fundado sobre a liberdade e age em vista da liberdade".
}

\begin{tabular}{|l|l|l|l|l|}
\hline Qevista Dialectus & Ano 2 & n. 4 & Janeiro-Junho 2014 & p. 39-62 \\
\hline
\end{tabular}


suprassumida pela filosofia, devemos sempre levar em conta o triplo sentido do termo suprassumir ou suspender (aufheben) na língua alemã e para Hegel, o qual não quer dizer que a religião deva vir a ser suprimida pela filosofia, ou seja, que essa deva vir a dar um fim àquela. Tal religião acaba, sim, sendo negada em parte, mas é, igualmente, conservada, apenas perdendo sua imediatidade, sem, com isso, deixar de ser. Ao final, na verdade, tal religião acaba sendo elevada com tudo isso. Ora, para D. Schneider: "Hegel procura uma melhor solução no âmbito da filosofia, mas sabe que não pode deixar de passar pelo nível e forma da religião. Isso tão somente porque a religião é mais imediata à autoconsciência do que a reflexão filosófica"; ou seja, "o senso comum em que eu vivo me é mais imediato do que as minhas reflexões filosóficas" (SCHNEIDER, 2003, p. 295).

Por isso, Hegel reconhece e estimula a religiosidade, sobretudo no Estado que não esteja segundo o princípio da liberdade tal como deveria estar, que não tenha vindo ainda a ser racional, o qual, em síntese, acaba sendo um Estado particular que meramente existe, mas ainda não efetivamente, pois não está articulado e organizado segundo a razão.

\begin{abstract}
Um mau Estado é um Estado que meramente existe; um corpo doente também existe, mas ele não tem nenhuma realidade verdadeira. Uma mão que está decepada também parece ainda com uma mão e existe, sem ser, contudo, efetivamente real: o que é real-efetivo é em si mesmo necessário. A necessidade consiste em que o todo esteja dirimido nas diferenças do conceito e que esse momento dirimido forneça uma determinidade sólida e duradoura, que não é rígida como a morte, mas que se engendra continuamente na [sua] dissolução. Ao Estado acabado pertence essencialmente a consciência, o pensamento; o Estado sabe por isso o que ele quer, e o sabe como algo pensado. Ora, visto que o saber tem a sua sede no Estado, tem-na, também, a ciência, aqui, e não a Igreja (HEGEL, 1998, §270 Z, p. 61).
\end{abstract}

Eis, destarte, um critério para saber se um Estado particular está ou não à altura do seu conceito; a saber, um Estado racional, segundo Hegel, é o que realiza, de forma efetiva, o conceito ou o princípio da liberdade.

\title{
Considerações Finais
}

Para Hegel, a religião, em sua forma de expressar a realidade, pode estar ocultando, sob o véu da crença religiosa, a verdade. Contudo, a religião, com o seu viés dogmático, muitas vezes, acaba apenas sofisticando o processo quando tenta exorcizar os problemas da humanidade com meros implantes doutrinários. Por isso, Hegel analisa a religiosidade, pois assim como os filósofos têm de estar preparados para argumentar

\begin{tabular}{|l|l|l|l|l|}
\hline Qevista Dialectus & Ano 2 & n. 4 & Janeiro-Junho 2014 & p. 39-62 \\
\hline
\end{tabular}


em favor de suas conclusões e de avaliar criticamente seus próprios argumentos, bem como todos os argumentos que lhes sejam apresentados, também quem não pretende vir a ser filósofo têm ainda a necessidade imperiosa de examinar os métodos pelos quais adquire ou expande seus conhecimentos. Para Hegel, o mais essencial da atitude do ser humano é a peculiar universalidade da postura crítica, decidida a não admitir nenhuma opinião ou tradição, sem antes analisá-la. A pretensão de verdade de uma opinião ou tradição só pode ser levada a sério quando se distinguiu e considerou, em separado e em conjunto, os diferentes passos e os distintos aspectos de seu processo de pensamento. Com isso, Hegel está comprometido com uma procura séria da razão de ser da existência humana e com o sentido e significado dela própria. Tomando consciência do que a existência é, o ser humano descobre a base a partir da qual tudo deve ser considerado e continuamente estudado. Desse modo, as dúvidas se tornam problemas. Mas, mesmo assim, é preciso permitir que os problemas sempre possam emergir, ou seja, não se deve repudiá-los de antemão. Que magnífica discrição sempre considerar com seriedade todos os problemas. Quem julga poder renunciar uma questão sem examiná-la com detida atenção, não está de posse do que de mais específico existe no filosofar, a inquietação profunda que coloca o ser humano em estado de prontidão para pensar.

Ora, Karl Marx, talvez um dos mais conhecidos representantes da esquerda hegeliana, no conhecido posfácio da $2^{\mathrm{a}}$ edição d'O Capital, enuncia a tese, que será retomada por toda uma geração de hegelianos, segundo a qual se trataria de retirar o invólucro teológico ou místico para descobrir o cerne racional do hegelianismo ${ }^{18}$. Ora, queira ou não, o certo é que Hegel sempre se considerou cristão (luterano ${ }^{19}$ ) e sempre se esforçou para demonstrar que nenhuma de suas teses estava em conflito com a fé cristã (cf. WEIL, 1970, p. 60). Hegel declarou, inclusive, que o cristianismo seria a religião da verdade e da liberdade e, sobretudo, se um Estado não fosse cristão, em seus fundamentos, então esse não seria um Estado da liberdade e da verdade (cf. Ibidem, p. $61)$.

Hegel destaca, ainda, que coube ao Cristianismo, na história da humanidade, o papel de proclamar que o homem é livre enquanto homem e que a liberdade é o que

\footnotetext{
18 "Critiquei a dialética hegeliana, no que ela tem de mistificação, há quase 30 anos, quando estava em plena moda. (...) A mistificação por que passa a dialética nas mãos de Hegel não o impediu de ser o primeiro a apresentar suas formas gerais de movimento, de maneira ampla e consciente. Em Hegel, a dialética está de cabeça para baixo. É necessário pô-la de cabeça para cima, a fim de descobrir a substância racional dentro do invólucro místico" (MARX, 1998, p. 16).

19 "Nós, os luteranos - eu sou luterano, e faço tenção de continuar a sê-lo" (HEGEL, 1974, p. 125).
}

\begin{tabular}{|l|l|l|l|l|}
\hline Qexista Dialectus & Ano 2 & n. 4 & Janeiro-Junho 2014 & p. 39-62 \\
\hline
\end{tabular}


caracteriza o ser humano. Com o acolhimento do espírito da verdade, o sujeito pode vir a se apropriar de si mesmo, enquanto ser livre, e a verdade pôde, enfim, se manifestar no seu ser livre. As grandes transformações na atualidade, segundo Hegel, se dão em função da construção de um mundo objetivo a partir do princípio da liberdade. Num Estado verdadeiramente racional, as leis e a mentalidade nada mais são do que a consumação do princípio da liberdade. É, portanto, segundo Hegel, necessário realizar, de forma sociopolítica, a verdade consubstancializada na religião cristã, contanto que a emancipação do Estado não conduza à loucura, que é a separação total entre a vida estatal e a religiosa. De acordo com Hegel, o que constituía a tragédia específica do seu tempo é a separação tornada comum entre o Estado e a religião.

Para Hegel, todos precisam reconhecer que o Estado e a religião ocupam lugares de capital importância na vida humana. Por isso, Estado e religião não são e não podem ser totalmente independentes. Ora, as autoridades estatais e religiosas devem ambas representar as aspirações de seu povo e se manter nos limites de suas competências. Enquanto o mundo se organiza na busca do bem comum temporal, entende-se que os detentores do poder agem em nome do povo e com a autoridade delegada pelo povo. Por isso, todo o povo deve, de algum modo, ser político, mesmo que alguns cidadãos o serão em grau mais elevado. Não tem, pois, sentido dividir povo e autoridade, como se os interesses de ambos fossem divergentes. Antes pelo contrário, não existe povo sem autoridade e nem autoridade sem povo. Não se pode, contudo, ignorar que as pessoas que são deputadas para exercer o poder - ou porque o conquistaram à força, ou porque se impuseram, ou porque o compraram, ou por mil outras maneiras - nem sempre se empenham pelo verdadeiro bem do povo que deveriam promover, quer por interesses egoístas, quer por falta de capacidade, quer pela orgia do poder, quer por outras razões. Que se requer, pois, para que exerçam sua verdadeira missão? Ora, a história foi e continua sendo a mestra da vida. Por exemplo, a maior parte das Igrejas hoje reconhece o direito à liberdade religiosa e não pretendem mais impor, como em concordatas do passado, que sejam proibidas as outras religiões; política que revertia em prejuízo para ela mesma, nos outros países em que seus fiéis se encontrassem em minoria. No início, o princípio da tolerância e da liberdade de consciência religiosa produziu embates com religiões que, considerado-se detentoras da verdade, não aceitavam que ela devia ser procurada livremente. Aparentemente não havia saída para o embate, pois, de um lado, havia aqueles que achavam que a verdade só se revelaria se houvesse condições de procurá-la livremente e, de outro lado, a convicção de que a verdade fora revelada e

\begin{tabular}{|l|l|l|l|l|}
\hline Qexista Dialectus & Ano 2 & n. 4 & Janeiro-Junho 2014 & p. 39-62 \\
\hline
\end{tabular}


devia ser ministrada hierarquicamente. Ora, cada um estava convencido de que estava defendendo o melhor preceito, pois do contrário talvez não teriam agido como agiram. Mas, de fato, todos queriam simplesmente o reconhecimento de que a religião deveria ficar livre de compromissos diretos com determinadas estruturas temporais e o Estado deveria poder ser soberano em seu encargo. Ou seja, fazendo a crítica do passado para reconhecer os acertos e os erros cometidos, pode-se proporcionar um subsídio para superar os impasses que poderiam levar a outros erros na atualidade e no futuro.

\section{Referências Bibliográficas}

AQUINO, Marcelo Fernandes de. O conceito de Religião em Hegel. São Paulo: Loyola, 1989.

BOURGEOIS, Bernard. "A Enciclopédia das Ciências Filosóficas de Hegel”. In: HEGEL, G. W. F. Enciclopédia das Ciências Filosóficas em Compêndio (1830): I A Ciência da Lógica. São Paulo: Loyola, 1995¹.

"Présentation". In: HEGEL, G. W. F. Encyclopédie des Sciences Philosophiques. I - La Science de la Logique. Paris: Vrin, 1970'.

Paris: J. Vrin, $1970^{2}$.

Hegel a Francfort ou Judaïsme-Christianisme-Hegelianisme.

O Pensamento Político de Hegel. Tradução de Paulo Neves da Silva. Coleção Ideias n ${ }^{\circ}$. São Leopoldo: Ed. UNISINOS, 2000.

HEGEL, G. W. F. Enciclopédia das Ciências Filosóficas em Compêndio (1830): I A Ciência da Lógica. Trad. de Paulo Meneses. São Paulo: Loyola, $1995^{1}$.

Enciclopédia das Ciências Filosóficas em Compêndio (1830): III - A Filosofia do Espírito. Trad. de Paulo Meneses. São Paulo: Loyola, $1995^{2}$.

Fenomenologia do Espírito. Trad. de Paulo Meneses. Vol. único $7^{a}$ ed. rev. Petrópolis: Vozes - Bragança Paulista: USP, 2002.

ed. Brasília: UnB, 1999.

Filosofia da História. Trad. de Maria Rodrigues e Hans Harden. $2^{\mathrm{a}}$

Filosofia do Direito (Linhas Fundamentais da Filosofia do Direito ou Direito Natural e Ciência do Estado em Compêndio). Tradução, notas, glossário e bibliografia de Paulo Meneses, Agemir Bavaresco, Alfredo Moraes, Danilo Vaz-Curado R. M. Costa, Greice Ane Barbieri e Paulo Roberto Konzen. Apresentações de Denis Lerrer Rosenfield e de Paulo Roberto Konzen. Recife, PE: UNICAP; São Paulo: Loyola; São Leopoldo: UNISINOS, 2010.

\begin{tabular}{|l|l|l|l|l|}
\hline Qevista Dialectus & Ano 2 & n. 4 & Janeiro-Junho 2014 & p. 39-62 \\
\hline
\end{tabular}


Filosofia do Direito (Linhas Fundamentais da Filosofia do Direito ou Direito natural e ciência do estado em compêndio) - Terceira parte: Eticidade Terceira seção: Estado. Trad. de Marcos Lutz Müller. Textos Didáticos $n^{\mathbf{o}} 32$. Campinas: IFCH/UNICAMP, 1998.

1974.

Introdução à História da Filosofia. Coimbra: Ed. Arménio Amado,

HELFER, Inácio. História e Liberdade em Hegel. Dissertação de Mestrado. Porto Alegre: UFRGS, 1991.

KOJÈVE, Alexandre. Introdução à leitura de Hegel. Rio de Janeiro: Contraponto EDUERJ, 2002.

MARX, Karl. O Capital: Crítica da Economia Política. Vol. I. Rio de Janeiro: Bertrand Brasil S. A., 1998.

MENESES, Paulo G. de. Hegel \& A Fenomenologia do Espírito. Rio de Janeiro: J. Zahar, 2003.

OLIVEIRA, Manfredo Araújo de. Tópicos sobre Dialética. Porto Alegre: EDIPUCRS, 1996.

ROSENFIELD, Denis Lerrer. "A Metafísica e o absoluto". In: Revista Filosofia Política. Série III, n 3. Rio de Janeiro: Jorge Zahar, 2002.

SCHNEIDER, Delmar E. Metafísica e Historicidade. São Leopoldo: UNISINOS, 2003.

VAZ, Henrique C. de Lima. "Por que ler Hegel hoje?". In: DE BONI, Luis A. (Org.). Finitude e Transcendência - Festschrift em homenagem a Ernildo J. Stein. Petrópolis: Vozes; Porto Alegre: EDIPUCRS, 1995.

WEIL, Eric. Hegel et l'État - Cinq Conférences. 6ª́dition. Paris: Vrin, 1985. Hegel y el Estado. Córdoba, Argentina: Ediciones Nagelkop, 1970.

\begin{tabular}{|l|l|l|l|l|}
\hline Qevista Dialectus & Ano 2 & n. 4 & Janeiro-Junho 2014 & p. 39-62 \\
\hline
\end{tabular}

